\title{
UTILIZATION OF REMOTE SENSING METHODS IN PROSPECTING OF ALKALINE ROCKS IN FINLAND
}

\author{
HEIKKI PAARMA and HEIKKI VARTIAINEN
}

PAARMA, HEIKKI, and VARTIAINEN, HEIKKI 1996. Utilization of remote sensing methods in prospecting of alkaline rocks in Finland and neighbouring areas. Bull. Geol. Soc. Finland 68, Part 1, 25-33.

The availability of various kind of satellite imageries and geological, geochemical and geophysical data in useful form has given possibility to confirm the earlier tectonic interpretations of deep fracture zones and to find new interesting zones for the exploring of alkaline rocks in Finland. The interpretations and suggestions given here are tentative prognoses for prospecting certain areas. The selecting of real target areas need more work. Some methods for this kind of classifying research for planning prospecting projects have been recommended. So far the Finnish Lapland is regarded as a region where the methods suggested here would give useful results.

Key words: Alkaline rocks, tectonics, deep fracture zones, satellite imageries, geodata, prospecting, prognosis methods, Finland

Heikki Paarma, Jaakonkuja 1 F, FIN-90230 Oulu, Finland

Heikki Vartiainen, Ministry of Trade and Industry, Aleksanterinkatu 4, FIN00170 Helsinki, Finland

\section{INTRODUCTION}

From the beginning of late 1950's unique tectonic models were used in Finland when planning areal prospecting projects. An important aspect was to pay attention to deep fractures as critical zones for prospecting of alkaline rock complexes. Also new anortosite-gabro massifs, containing V-, Ti-, Fe-ores, similar to at that time active Otanmäki mine, were believed to be discovered. The background idea was to improve the economy of the iron ore mining by bypro- duction of niobium, vanadium or titanium. There were many foreign examples of this kind.

Weather satellite imagery was available from the beginning of the 1960 's. The cloudless imageries made it possible to use them with other geodata in localization of deep fracture zones. Some Tiros and Essa imageries were guiding the ore prospecting activity, which ultimately caused the discoveries of the Sokli, Laivajoki and Kortejärvi carbonatites in Finland.

Prognoses of alkaline rocks tectonics, based on the new structural tectonic materials and other geodata, are discussed in the following. 


\section{ALKALINE ROCKS AND GLOBAL TEC- TONICS}

Increasing global knowledge of alkaline rocks and their distribution has progressed possibilities to connect genetically alkaline rock zones and provinces to the structure of the crust. East African alkaline rocks are associated with thousands of kilometers long rift valley system. Corresponding large scale structures were outlined to Europe by Kukharenko (1967). According to him, alkaline rocks of Kola and Oslo jord belong to the diagonal system beginning from Southern Norway and continuing through the Rhein-Graben to the Rhone valley. Gorbunov et al. (1978) regarded later NE-SW oriented multiple deep frature zone system as the control of the occurence of alkaline rocks. Negrutsa (1978) has shown also W-E oriented deep fracture system. Beljaev et al. (1977) suggested that the circular tectonics characterizes the Kola alkaline rock province.

The Sokli carbonatite complex was disvovered in 1967. The observations from the weather satellite (TIROS- and ESSA-series) in the beginning of 1960 's pointed to possibilities that the deep fractures controlling the alkaline rocks of Kola could continue to the Finnish side (Fig. 1). The lineaments of the Fig. 1 are showing the earliest tectonic interpretations of that time (Paarma, $\mathrm{H}$. 1970). The discovery of Sokli confirmed later the presence of SE-NW oriented alkaline rock containing deep fracture zone (Paarma \& Talvitie, 1977). This fracture can be a part of the global deep fracture system.

Bush (1983) has studied deep fractures all over the Eurasia and found a transcontinental N-S oriented rift type, deep fracture system, which is more regular and better developed than the diagonal systems. Plate tectonic models are also used for understanding of the global distribution of alkaline rocks (Doing, 1970).

\section{LOCAL TECTONICS OF ALKALINE ROCKS}

In spite of 360-380 Ma (Kramm et al. 1993) old alkaline rocks and carbonatites, also precambrian ones occur in Finland and in Kola (Vartiainen and Woolley 1974).

The lineament I-I in Fig. 2, which was interpreted from TIROS weather satellite imagery, was a basis to localize precambrian Kortejärvi, Laivajoki and Halpanen carbonatites. Siilinjärvi carbonatite was known earlier (Puustinen, 1971).

The age determinations made from the carbonatites and gabros occuring within the submeridian fracture zone I-I (Fig. 2) indicate repeated activity of this fracture zone.

Other geodata refers also to the possible much later activity of this zone as shown by the combination of geological and geophysical data in Fig. 3.

There are several submeridian deep fractures in Finland and in the neighbouring areas. It is possible that some of these submeridian fracture zones could contain alkaline rocks of different ages. The following examples are indicative references. In Sweden so called Protogen zone is a submeridian one. Two paleozoic alkaline rocks (Norra Kärr and Särna) are localized beside it. Alkaline lamprophyres or kimberlites of Kalix in Northern Sweden and the Stjernöy alkaline rock complex can be associated with the submeridian tectonics (Fig. 2). The boulders presented in Fig. 2 are not yet localized into the bedrock. The most interesting is astrophyllite bearing nefeline syenite boulder found from North Karelia (Eskola \& Shalstein, 1936). The source rock of this boulder has not prospected on the basis of the tectonic interpretations presented here. Also can be stated that the submeridian lineament east from the lineament I-I (Fig. 2) continues to south into the Karelian Isthmus as a paleozoic fracture (Uvadjev, 1978).

Kumarapeli and Saull (1966) have presented that in St. Lawrence valley system, in addition to alkaline rocks, occur also kimberlites. In literature there are several examples of the close genetic and tectonic relations between alkaline rocks and kimberlites. The new discoveries of diamond bearing kimberlites in Kantalaksha deep fracture and in its continuation in Arkangelsk area have given additional support for prospecting of alkaline rocks on the basis of the deep fracture tectonic research. 


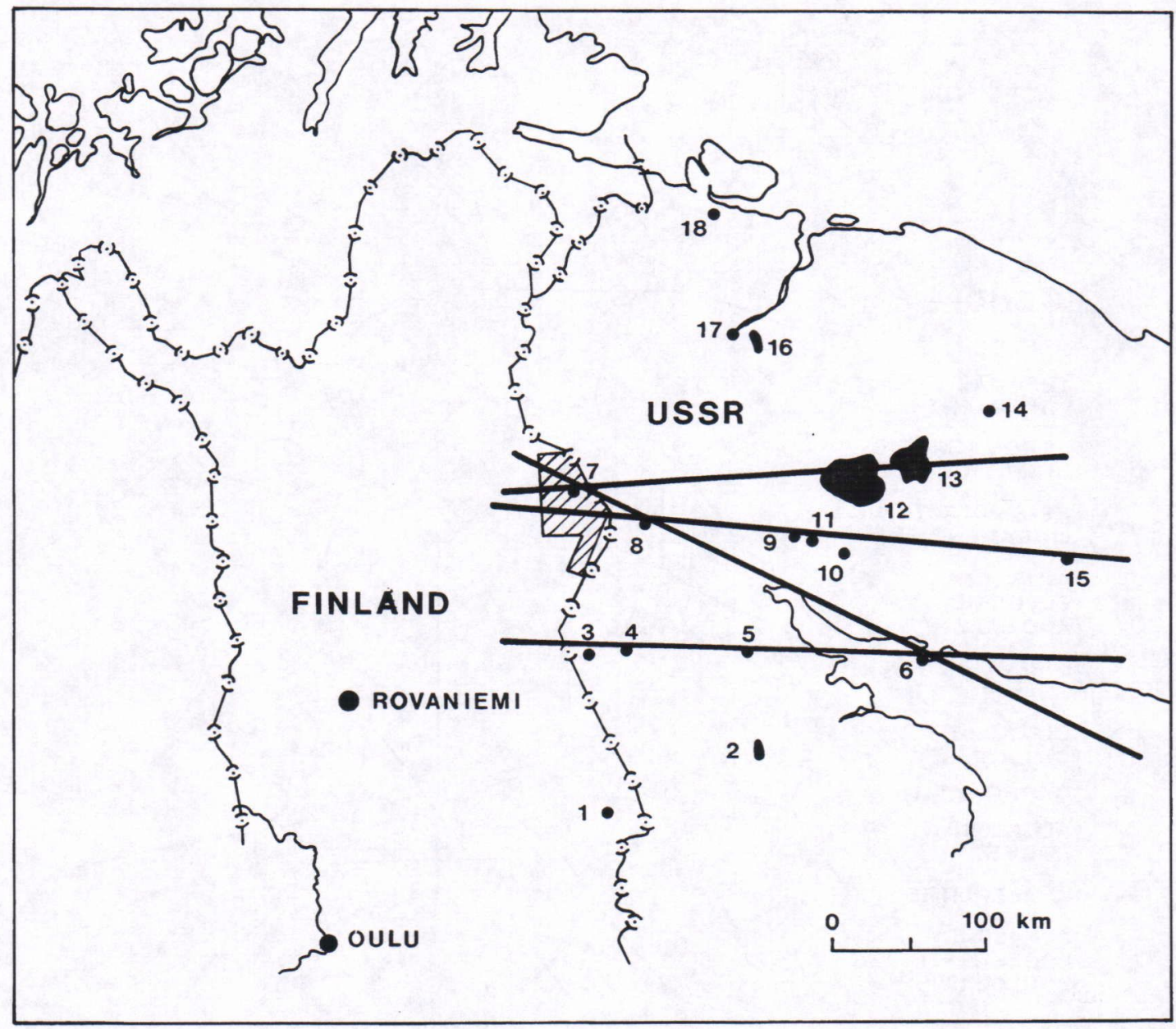

Figure 1. The alkaline rocks of north eastern Fennoscandia with supposed tectonic zones before finding of the Sokli carbonatite massif. Shaded: area of prospecting in 1967. 1 Iivaara, 2 Jelettijärvi, 3 Sallanlatva, 4 Vuorijärvi, 5 Koutajärvi, 6 Tury, 7 Sokli, 8 Kovdor, 9 The Habozersk group, 10 Salmagorsk, 11 Soustovsk, 12 Khibina, 13 Lovozero, 14 Kontozersk, 15 Pesoi River, 16 Gremjaha-Vyirmes, 17 Sebljavrsk,18 Tsagve-Oaivu.

RECOMMENDATIONS FOR AREAL PROSPECTING OF ALKALINE ROCKS, CARBONATITES AND KIMBERLITES

The kind of tectonic model compiled and interpreted by Paarma and Kuosmanen (1993) as presented in Fig. 2 is suitable only for preliminary prognosis. This tectonic model ought to be improved by many methods. Only one model is not enough for plannning prospecting projects.
Thus the prospecting efforts of alkaline rocks are better to direct to the crossing areas of deep fractures. The preliminary prognosis presented in Fig. 4 is compiled using our present interpretation of large scale tectonics and other geodata so as the circular structures seen in Fig. 2.

At the same time when the preliminary prognosis map will be completed, more detailed interpretations should be done on the most interesting areas of the prognosis map (Fig. 4). There are plenty 


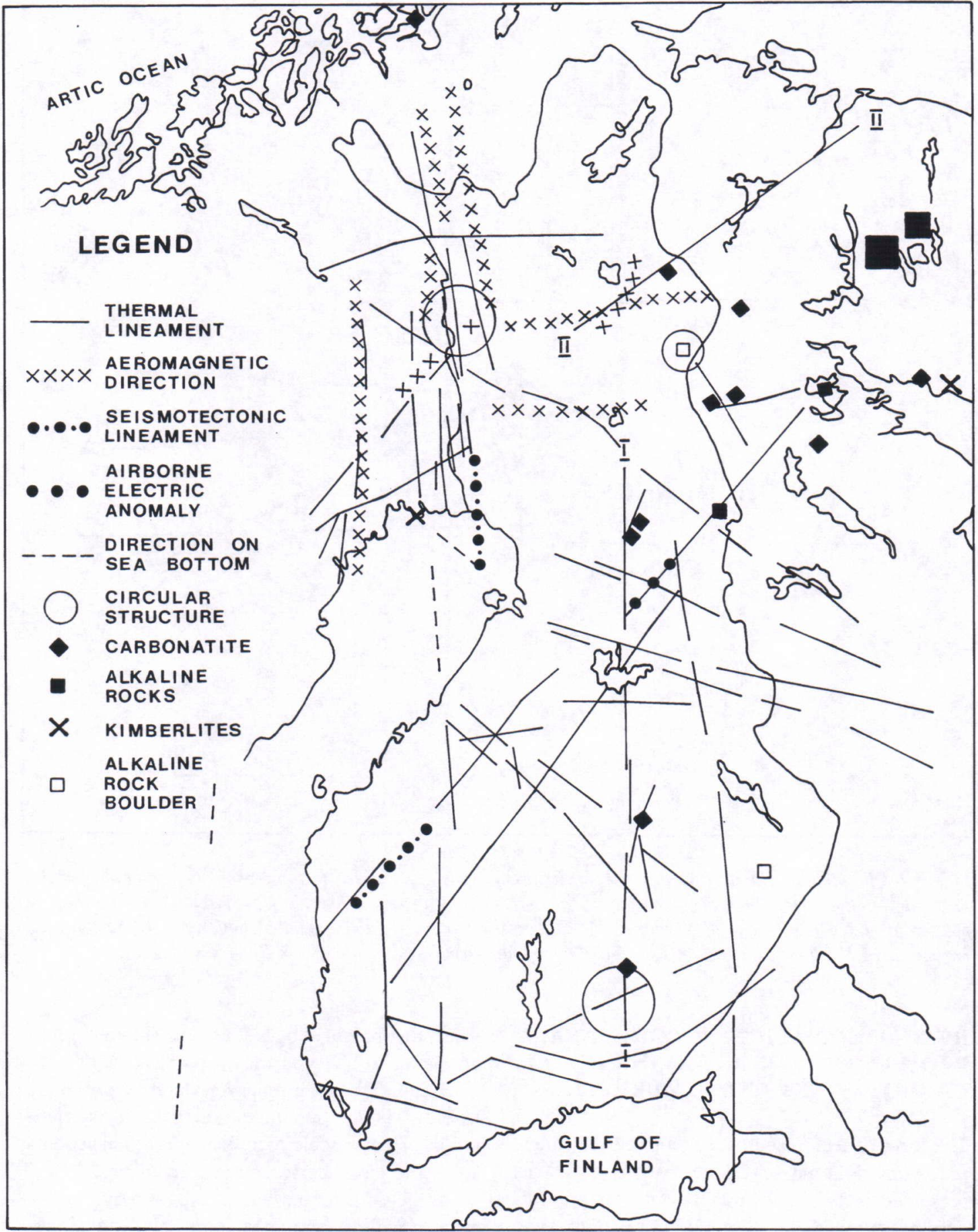

Figure 2. The interpretation map by Paarma and Kuosmanen (1993) supplemented by some geological and tectonic data. 


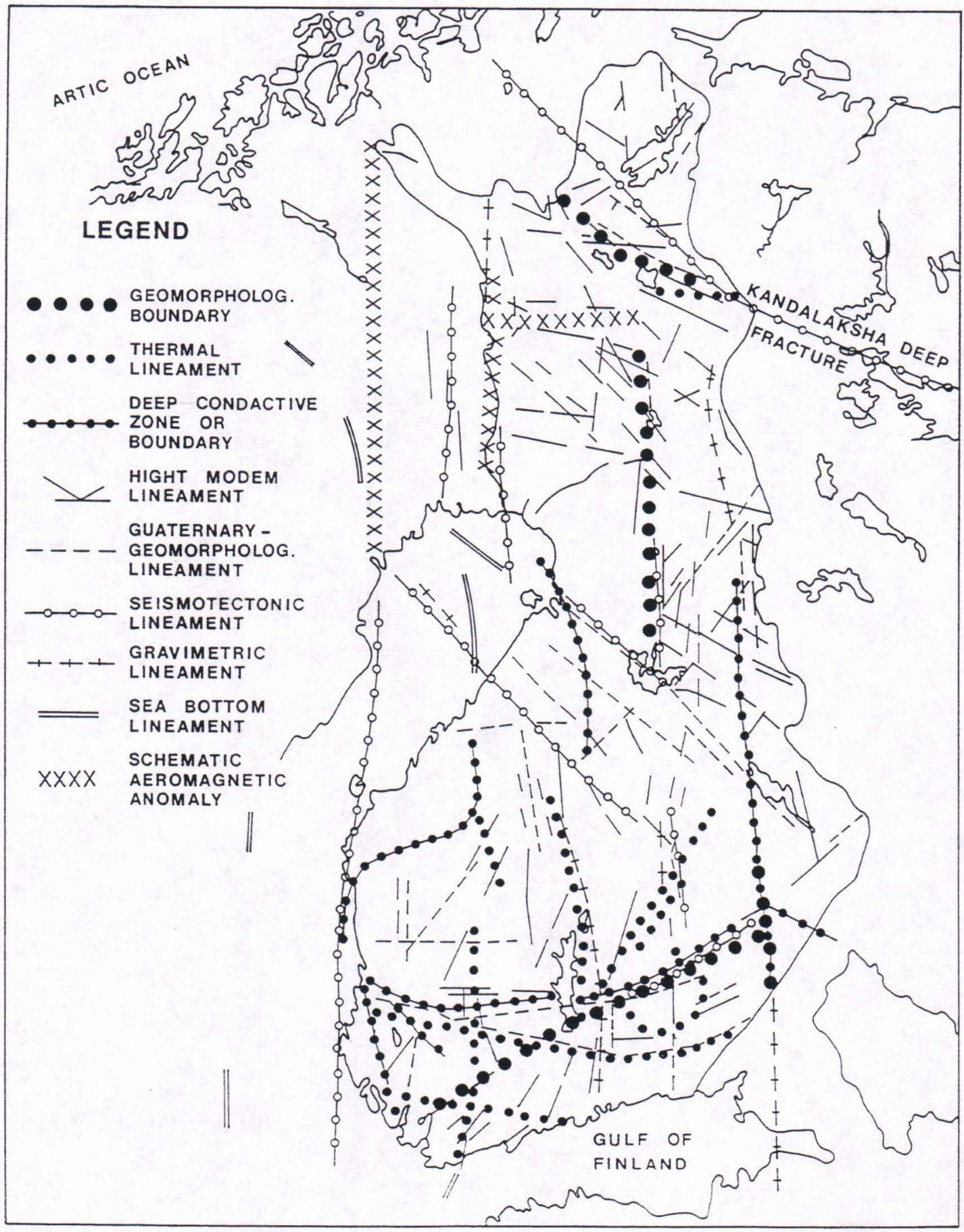

Figure 3. Selected geophysical, geological, geochemical, geomorphological and satellite lineaments of Finland (collected by Paarma). 
Heikki Paarma and Heikki Vartiainen

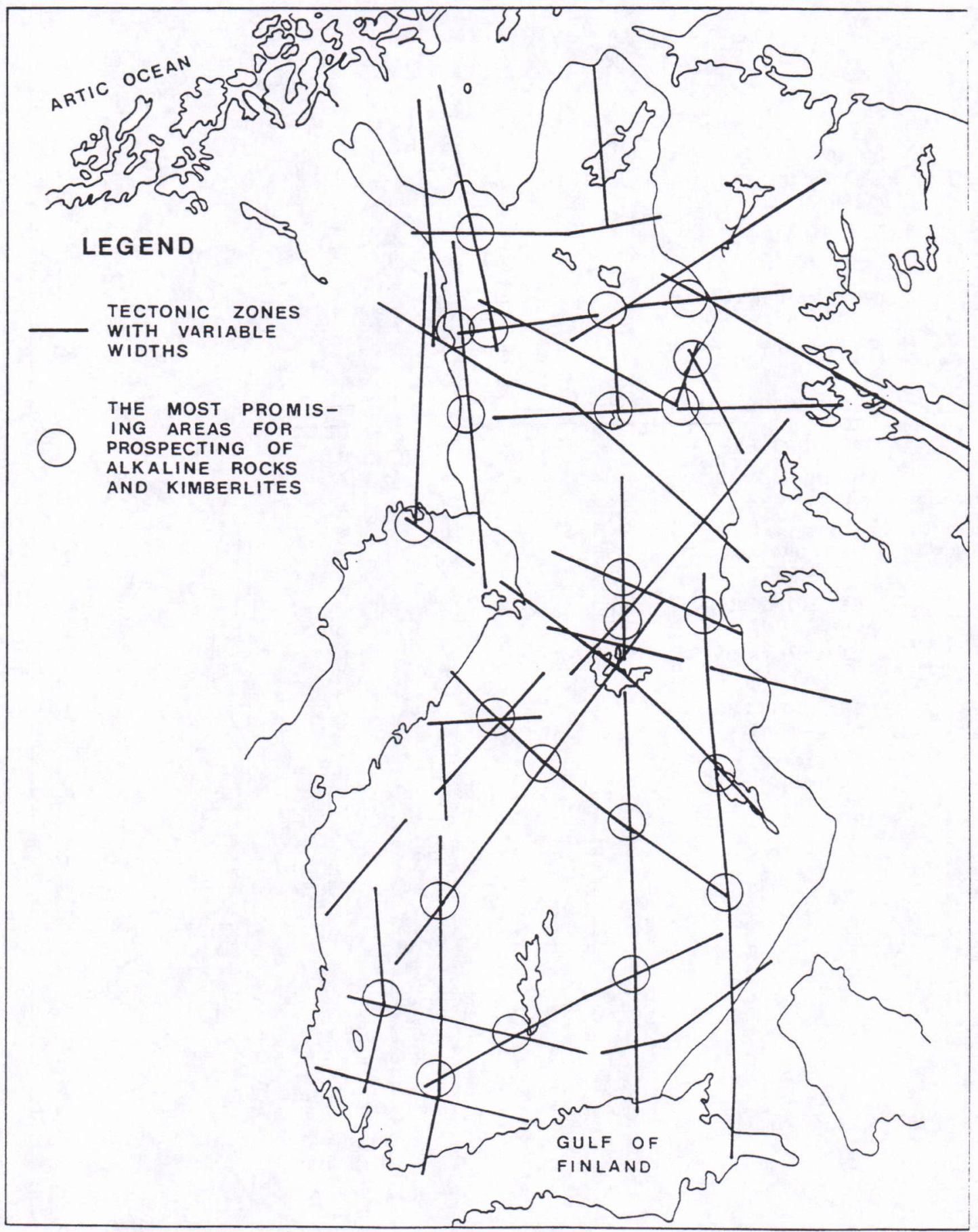

Figure 4. Simplified preliminary lineament model over Finland and suggestions for target areas for prospecting alkaline rocks and kimberlites. 
of undrilled magnetic and radioactive anomalies in Finland. When choosing these for prospecting targets, the tectonic interpretations presented here could help in prognostification the most interesting places. By this method the Kortejärvi and Laivajoki carbonatites were discovered. Also the surrounding areas of known carbonatites and alkaline rocks are perspective for prospecting. Such a local

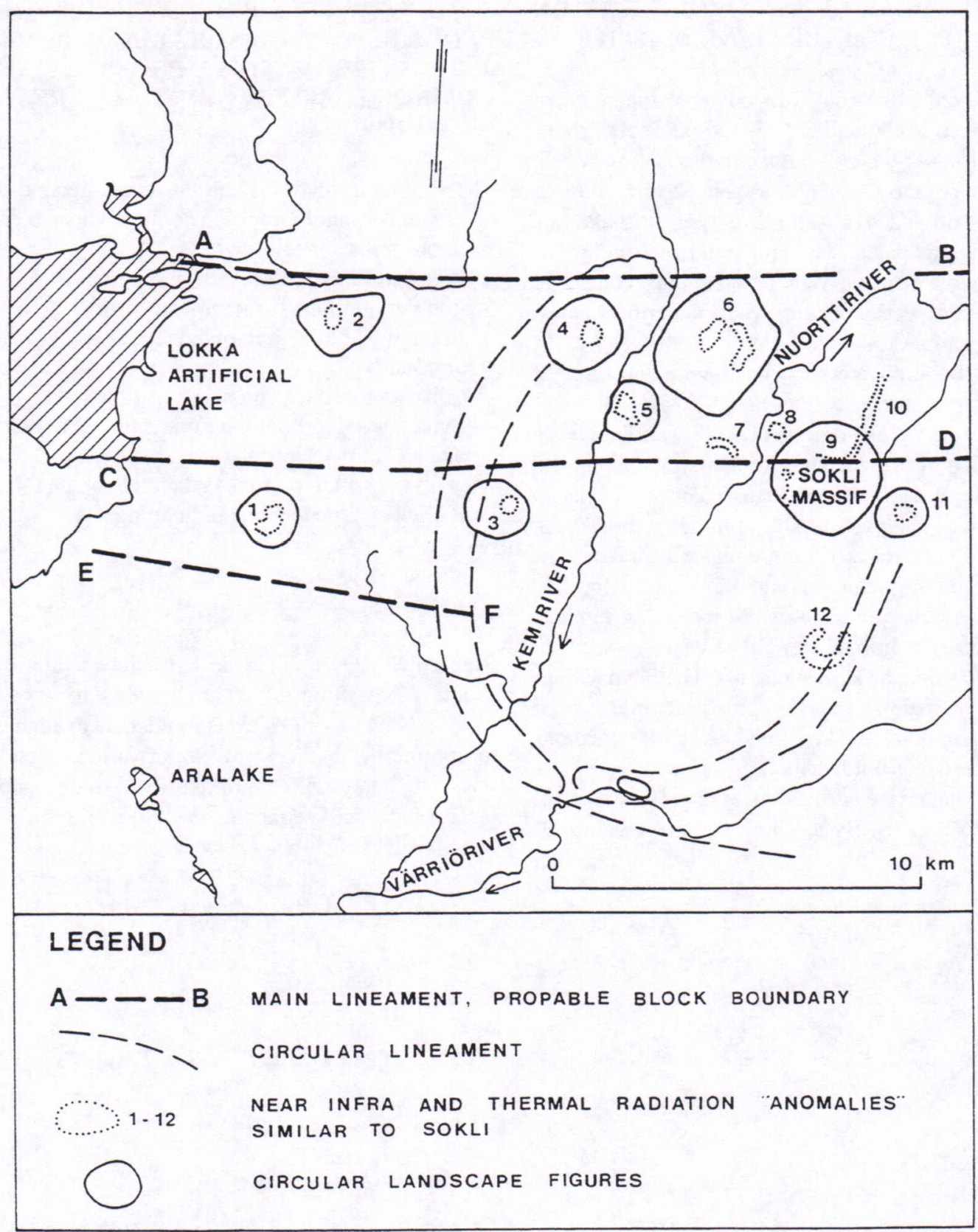

Figure 5. An example of local prognosis for prospecting targets based on satelite imaginary interpretation. Modified from Paarma (1992). 
prognosis bases on remote sensing is shown in Fig. 5.

\section{SOME IDEAS OF THE LOCALIZATION OF SEPARATE ALKALINE MASSIFS}

All the alkaline rocks do not give magnetic or radioactive anomalies. Also Sokli could have been found by geochemical methods (Vartiainen, 1976). All the geodata so as geochemical anomalies of till and river sediments typical to alkaline rocks,geophysical anomalies and interpretations of remote sensing ought to be thus combined when prospecting alkaline rocks on critical areas. For example it should be checked if $\mathrm{Nb}, \mathrm{La}, \mathrm{Zr}$, $\mathrm{Sr}$ or $\mathrm{Ba}$ high are associated with the circular structures in Fig. 5 (Paarma, 1992).

During the exploration of Sokli, various special methods of interpretation of aerophotographs and satellite imageries were tested. The weak glacial dynamics is typical to glacial divide regions such as the Sokli area is. On these regions, for example, false colour pictures could be used to localize small circular targets possibly indicating kimberlite pipes or new alkaline rocks and carbonatite dikes outside the known massifs. The Finnish Lapland is a region where combined interpretation of aerophotograps and geo- and biochemical methods would give useful results.

In Finland we have plenty of unprofessional ore boulder hunters. By teaching them to identify al- kaline rocks and carbonatites and especially fenites, we could promote to get new prospects.

\section{SOME NEW POSSIBLE METHODS FOR PROGNOSIS OF ALKALINE ROCK AND CARBONATITE PROSPECTING COMBINED WITH GENERAL AREAL METHODS}

The following methods can be recommended:

- colour aerophotographs in autumn, when deciduous trees are coloured

- high level false colour aerophotographs

- boulder hunting, as mentioned before

- exploring of mini diamonds from fluvial gravel and sands

- utilizing foreign references

- remote sensing: night thermal and other channels

- analyzing alkaline rock critical elements $(\mathrm{Nb}$, REE, Ta) in geochemical mapping

\section{CONCLUSIONS}

Rautaruukki Oy applied deep fracture tectonics to the prospecting of alkaline rocks in 19601970 's. Now in 1990's excellent data is available to continuing that kind of work. Various methods, which are only preliminarily tested, could promote this task either in the interpretation of large scale structures or local prospecting objects. 


\section{REFERENCES}

Belyaev, K., Proskuryakov, V., Korsakova, M., Rabinovich, Y., Zagorodny, V., Bylinski, R. \& DolivoDobrovolski, A. 1977. The tectonic pattern of the eastern part of the Baltic Shield. In: Caj Kortman (ed.) Fault tectonics in the eastern part of the Baltic Shield: Proceedings of a FinnishSoviet Symposium held in Finland, 20th24th September, 1976. Helsinki, 35-48.

Bush, V.A. 1983: Systems of transcontinental lineaments in Eurasia. Geotectonics 17 (3), 186-200.

Doig, R. 1970: An alkaline rock province linking Europe and North America. Canadian Journal of Earth Sciences 7 (1), 22-28.

Eskola, P. \& Sahlstein, TH.G. 1930: On astrophyllitebearing nephelite syenitegneiss found as a boulder in Kiihtelysvaara, eastern Finland.Bulletin de la Commission géologique de Finlande 92, 77-78.

Gorbunov, G.I., Makijevski S.I., \& Nikolajeva, K.A. 1978: Metallogenitseskaja zonal'nost, svjazannaja s tektonomagmatitseskoj aktivizatsiej Baltijskogo scita. Sovetskaja Geologija 4/1978, 15-26.

Kramm, U., Kogarko, L. N., Kononova, V. A. \& Vartiainen, H. 1993. The Kola alkaline province of the CIS and Finland: precise RbSr ages define $380360 \mathrm{Ma}$ age range for all magmatism. Lithos 30 (1), 33-44.

Kukharenko, A.A. 1967: Alkaline magmatism of the eastern part of Baltic Shield (in Russian). Zapiski Vsesoyuznogo Mineralogicheskogo Obshchestva 96 (5), 547-566.

Kumarapeli, P.S. \& Saull, V.A. 1966: The St. Lawrence valley system: A North American equivalent of the East African rift valley system.Canadian Journal Earth Sciences 3 (5), 639658.

Negrutsa, V.Z. 1978. Stages of the geological development of eastern part of the Baltic Shield and the metallogenetic specialization (in Russian). In: V.Z. Negrutsa (ed.) Geologitšeskije predposylki perspektiv rudonosnosti dokembrija vostotšnoi tšasti Baltiiskogo štšita. Moskova, Min. Geol. RSFSR, 6-13.

Paarma, H. 1970. A new find of carbonatite in North Finland, the Sokli plug in Savukoski. Lithos 3 (2), 129-133.

Paarma, H.\& Kuosmanen, V. 1993. Lineamenttihavaintoja NOAA-yölämpökuvista. In: Mertanen, S., Laiho, A. \& Tattari, S. (eds.) XVI Geofysiikan päivät, kaukokartoituksen päivät Espoossa 11.12.5.1993. Espoo: Geofysiikan Seura: Fotogrammetrian ja kaukokartoituksen Seura, 217-223.

Paarma, H. \& Talvitie, J. 1976. Deep fractures - Sokli carbonatite. University of Oulu. Department of Geophysics. Contribution 65.5 p. +3 app. fig.

Paarma, H., Vartiainen, H. \& Penninkilampi, J. 1977. Aspects of photogeological interpretation of Sokli carbonatite massif. In: Prospecting in areas of glaciated terrain 1977: papers presented at a symposium organized by the Institution of Mining and Metallurgy and held in Helsinki, Finland, on 15-17 August, 1977. London: Institution of Mining and Metallurgy, 25-29.

Puustinen, K. 1971. Geology of the Siilinjärvi carbonatite complex, eastern Finland. Bulletin de la Commission Géologique de Finlande 249. 43 p. +1 app. map.

Uvadyev, L. 1978. Late proterozvic and paleozoic activation of the eastern part of the Baltic Shield (in Russian). In: V.Z. Negrutsa (ed.) Geogitšeskije predposylki perspektiv rudonosnosti dokembrija vostotšnoi tšasti Baltiiskogo štšita. Moskova, Min Geol. RSFSR, 125-139.

Vartiainen, H. 1976. Sokli: carbonatite prospecting by the heavy minerals in stream sediments. Journal of Geochemical Exploration 5 (3), 335-337.

Vartiainen, H. \& Paarma, H. 1979. Geological characteristics of the Sokli carbonatite complex, Finland. Economic Geology 74 (5), 1296-1306.

Vartiainen, H. \& Woolley, A. R. 1974. The age of the Sokli carbonatite, Finland, and some relationships of the North Atlantic alkaline igneous province. Bulletin of the Geological Society of Finland 46 (1), 81-91. 